\title{
Anti-nociceptive effects of Paecilomyces hepiali via multiple pathways in mouse models
}

\author{
C. Wang ${ }^{1 *}$, J. Wang ${ }^{1 *}$, D. Jia ${ }^{1}$, L. Li ${ }^{1}$, B. Jia ${ }^{1}$, S. Fan $^{1}$, J. Song ${ }^{1}$, X. Hu${ }^{2}$, \\ Y. Wang ${ }^{1}$ and D. Wang ${ }^{1}$ \\ ${ }^{1}$ School of Life Sciences, Jilin University, Changchun, China \\ ${ }^{2}$ Faculty of Clinical Medicine, Changchun Medical College, Changchun, China \\ Corresponding authors: Y. Wang / D. Wang \\ E-mail: wyw@jlu.edu.cn / jluwangdi@outlook.com
}

Genet. Mol. Res. 15 (3): gmr. 15038996

Received July 21, 2016

Accepted August 1, 2016

Published August 30, 2016

DOI http://dx.doi.org/10.4238/gmr.15038996

Copyright (C) 2016 The Authors. This is an open-access article distributed under the terms of the Creative Commons Attribution ShareAlike (CC BY-SA) 4.0 License

\begin{abstract}
Paecilomyces hepiali (PH), a well-known medicinal fungus, has various pharmacological efficacies. In our study, the antinociceptive effects of $\mathrm{PH}$ and underlying mechanisms were evaluated using various mouse models. An acetic acid-induced writhing test, hot plate test, and formalin test were employed to evaluate the antinociceptive activities of PH. The levels of neuronal nitric oxide synthase (nNOS) in the hypothalamus and monoamine neurotransmitters in the serum and hypothalamus of experimental mice were examined. Additionally, hot plate tests using mice pretreated with various antagonists were used to determine the mechanisms of PHmediated antinociception. The PH-enhanced latency period of mice in the hot plate test was significantly blocked by pretreatment with atropine and glibenclamide. PH shortened the phase I and phase II reaction times of formalin-treated mice. Strongly reduced writhing and stretching induced by acetic acid were observed in PH-treated mice,
\end{abstract}

Genetics and Molecular Research 15 (3): gmr.15038996 
indicating that $\mathrm{PH}$ mainly exerts antinociceptive activity on neurogenic pain. After thermal pain stimulation for $30 \mathrm{~s}$, compared to control mice, 7-day PH-treated mice had lower nNOS and dopamine levels, and increased levels of serotonin in both the serum and hypothalamus. Collectively, our data showed that $\mathrm{PH}$ mediated antinociceptive activities via multiple pathways, including monoamines, nNOS/ATPsensitive $\mathrm{K}^{+}$channels, and M-type acetylcholine receptors.

Key words: Paecilomyces hepiali; Antinociception; Monoamines; $\mathrm{nNOS} ; \mathrm{K}_{\mathrm{ATP}} ; \mathrm{mAChR}$

\section{INTRODUCTION}

Pain is typically caused by intense or damaging stimulation and is characterized by an unpleasant feeling. Among patients with common diseases who seek medical attention, pain management is often unsatisfactory (McCarberg, 2011). Rather than analgesic monotherapy, pain requires in-depth assessments and multiple therapeutic modalities. The failure of pain treatment causes unnecessary suffering and the exacerbation of physical conditions.

Currently, medications are the main therapeutic schedule for pain. Two analgesic drug types, i.e., opioid analgesics and non-steroidal anti-inflammatory drugs (NSAIDs), are applied in clinical settings (Rossato et al., 2015). Although morphine and other opioids contain essential analgesics that alleviate pain, patients are plagued by major side effects, such as analgesic tolerance, hyperalgesia, and drug dependence (Trang et al., 2015). Owing to their anti-inflammatory, antipyretic, and analgesic activities, NSAIDs are the most commonly used agents against chronic pain, rheumatism, and pyrexia. Although NSAIDs are perceived as safe for short-term usage, adverse effects in long-term usage pose a risk to patients (Magiera et al., 2013), including gastrointestinal bleeding, acute kidney injury, and cardiovascular risk. Accordingly, there is demand for alternative painkillers with few side effects.

Owing to their minimal side effects and various pharmacological activities, herbal medicines are considered a valuable reservoir for novel drugs (Cui et al., 2013). A number of patients who experience pain symptoms are successfully treated with herbal medicines. Tou-Feng-Yu Pill, a common Chinese medicine formula, displays anti-nociceptive effects on migraines by modulating the levels of neurotransmitters and bioactive substances ( $\mathrm{Li}$ et al., 2011). Our group successfully verified that Jia-Yuan-Qing Pill exerts significant antinociception effects via the regulation of peripheral nerves, without toxicity or physical dependence (Tian et al., 2014). Cordyceps sinensis, one of the most well-known traditional Chinese medicines, displays antidepressant-like activity via the modulation of the adrenergic and dopaminergic systems (Nishizawa et al., 2007). Paecilomyces hepiali, a parasitic fungus generally found in $C$. sinensis, contains similar chemical constituents and displays similar bioactivities as $C$. sinensis (Wu et al., 2016). Our group demonstrated its anti-depression activities, which were associated with the modulation of dopamine (DA) and serotonin (5-HT) levels in the hypothalamus. It has been hypothesized that fermentation mycelia of Paecilomyces hepiali (PH) may have antinociceptive properties related to the regulation of inflammatory factors and/or neurotransmitters.

In the present study, the biological activities of $\mathrm{PH}$ related to pain and the mechanisms

Genetics and Molecular Research 15 (3): gmr.15038996 
underlying its effects were analyzed in mouse models. The levels of neuronal nitric oxide synthase (nNOS) in the hypothalamus as well as DA and 5-HT in the serum and hypothalamus were detected using enzyme-linked immunosorbent assays (ELISA). Using hot plate tests with antagonist-pretreated mice, the mechanism underlying the effects of $\mathrm{PH}$ was examined.

\section{MATERIAL AND METHODS}

\section{Paecilomyces hepiali submerged fermentation}

A mutant PH strain with respect to the original strain, which was purchased from the Research Center for Entomogenous Fungi at Anhui Agricultural University, China (Preservation No.: RCEF 1429), was identified by the Chinese Academy of Sciences and preserved in the China Center for Type Culture Collection in Wuhan (Preservation No.: CCTCC M 2014670).

$\mathrm{PH}$ was cultured in a 100-L full-automatic fermentor (BaoXing Bioscience Company, Shanghai, China) with medium containing $30 \mathrm{~g} / \mathrm{L}$ sucrose, $10 \mathrm{~g} / \mathrm{L}$ peptone, $18 \mathrm{~g} / \mathrm{L}$ yeast extract powder, $3.0 \mathrm{~g} / \mathrm{L} \mathrm{MgSO}{ }_{4} \cdot 7 \mathrm{H}_{2} \mathrm{O}, 3.0 \mathrm{~g} / \mathrm{L} \mathrm{KH}_{2} \mathrm{PO}_{4} \cdot 3 \mathrm{H}_{2} \mathrm{O}, 10 \mathrm{~g} / \mathrm{L}\left(\mathrm{NH}_{4}\right)_{2} \mathrm{SO}_{4}, 0.011 \mathrm{~g} / \mathrm{L} \mathrm{ZnCl}_{2}$, and $0.25 \mathrm{~g} / \mathrm{L}$ vitamin $\mathrm{B}_{1}$. The fermentation conditions were as follows: the loading volume was $70 \mathrm{~L} / 100 \mathrm{~L}$, initial $\mathrm{pH}$ was 6.5 , rotation speed was $300 \mathrm{rpm}$, ventilation volume was 200 $\mathrm{L} / \mathrm{h}$, culture temperature was $26^{\circ} \mathrm{C}$, inoculum age was 3.5 days, and inoculum size was $5 \%$. The resulting PH mycelium was freeze-dried and provided directly to experimental mice. All chemical reagents used in the submerged fermentation process were obtained from SigmaAldrich (St. Louis, MO, USA).

\section{Animal experiments}

The animal experimental protocol was approved by the Animal Ethics Committee of Jilin University. BALB/c female mice (Six weeks old, 18-22 g; purchased from Norman Bethune University of Medical Science, Jilin University) were maintained on a 12-h light/dark cycle (lights on 07:00-19:00) at a temperature of $23^{\circ} \pm 1^{\circ} \mathrm{C}$ with water and food available $\mathrm{ad}$ libitum. Eight hours before the experiment, animals were deprived of food.

\section{Anti-nociceptive activity measurement}

BALB/c mice were randomly divided into five groups $(\mathrm{N}=12 /$ group; female) and orally treated with $10 \mathrm{~mL} / \mathrm{kg}$ double distilled (D.D.) water (Control group), $5 \mathrm{mg} / \mathrm{kg}(0.2 \mathrm{~mL})$ tramadol (Tra; Purchased from CSPC Pharmaceutical Group, Shijiazhuang, China, Positive control group), and $\mathrm{PH}$ at doses of 200,500 and $1000 \mathrm{mg} / \mathrm{kg}(0.2 \mathrm{~mL})$ once daily for 7 days. Thirty minutes after the last administration, the following experiments were performed.

\section{Acetic acid-induced writhing test}

Mice were intraperitoneally injected with a $1.0 \%$ aqueous solution of acetic acid $(10 \mathrm{~mL} /$ $\mathrm{kg}$ body weight). After $5 \mathrm{~min}$, each mouse was placed in a transparent observation cage, and the number of writhing events within 20 min was counted. Body writhing was defined as a contraction of the abdominal muscles together with stretching of the handsaw (Bonkanka et al., 2011).

Genetics and Molecular Research 15 (3): gmr.15038996 


\section{Hot plate test}

Latency to the first sign of hindpaw licking or jumping to avoid nociception was considered an index of the pain threshold. Mice were placed on a hot plate with a constant temperature of $55^{\circ} \pm 0.5^{\circ} \mathrm{C}$, and the paw withdrawal latency was recorded. Pain threshold was recorded as $60 \mathrm{~s}$ if the reaction time was longer than $60 \mathrm{~s}$ (Sudo et al., 2015).

\section{Formalin test}

Mice were injected with $2 \%$ formalin on the right hind paw and immediately placed in an elevated clear observation chamber. The process of nociceptive behaviors was divided into the early phase (0-5 min after injection) and the late phase (15-30 min after injection), which were recorded for $30 \mathrm{~min}$ immediately following formalin injection (Lee et al., 2015).

\section{Sample collection and biochemical index analyses}

At 30 min after the last administration of drugs, ten mice in each group were placed on a surface, which was heated to $55^{\circ} \pm 0.5^{\circ} \mathrm{C}$ for $30 \mathrm{~s}$. Another 10 mice in each group did not receive the thermal stimulus. Blood samples were collected from the caudal vein. The hypothalamus was quickly removed from the brain, and one part was dissected, weighed, and lysed with D.D. water.

The concentrations of nNOS in the hypothalamus and DA and 5-HT in the serum and hypothalamus were measured using commercially available ELISA kits (R\&D Systems, Minneapolis, MN, USA) following the manufacturer's instructions.

\section{Evaluation of the underlying mechanism}

Based on the hot plate test, the roles of opioid receptors, ATP-sensitive $\mathrm{K}+$ channels $\left(\mathrm{K}_{\mathrm{ATP}}\right), \mathrm{Ca}^{2+}$ channels, M-type acetylcholine receptors (mAChR), endogenous guanylyl cyclase, and/or a2-adrenoceptors in antinociceptive activity were assessed. Yohimbine, glibenclamide, and nimodipine were dissolved in a $1 \%$ DMSO aqueous solution. Other drugs were dissolved in D.D. water. Female BALB/c mice were intraperitoneally injected with naloxone $(1 \mathrm{mg} / \mathrm{kg})$, glibenclamide $(2 \mathrm{mg} / \mathrm{kg})$, nimodipine $(10 \mathrm{mg} / \mathrm{kg})$, atropine $(5$ $\mathrm{mg} / \mathrm{kg})$, methylene blue $(10 \mathrm{mg} / \mathrm{kg})$, and yohimbine $(2 \mathrm{mg} / \mathrm{kg})$. After $15 \mathrm{~min}$, mice were orally treated with PH $(1000 \mathrm{mg} / \mathrm{kg} ; 0.2 \mathrm{~mL})$ or D.D. water $(0.2 \mathrm{~mL})$. Normal mice treated with D.D. water $(0.2 \mathrm{~mL})$ served as the control group. Thirty minutes after administration, mice were placed on a hot plate with a constant temperature of $55^{\circ} \pm 0.5^{\circ} \mathrm{C}$, and the paw withdrawal latency was recorded.

\section{Statistical analysis}

All experiments were repeated at least three times. Data are expressed as means \pm SEM and analyzed using a one-way analysis of variance (ANOVA) followed by post-hoc multiple comparisons (Dunn's test). The differences were considered significant at $\mathrm{P}<0.05$.

Genetics and Molecular Research 15 (3): gmr.15038996 


\section{RESULTS}

\section{Antinociceptive effects of $\mathrm{PH}$ in mice}

Tramadol, which served as a positive control in the experiments, resulted in a $43.3 \%$ decrement in body writhing in the acetic acid-induced writhing test $(\mathrm{P}<0.01$; Figure $1 \mathrm{~A})$ and a $30.1 \%$ increment in the latency period of mice on the hot plate compared with untreated mice $(\mathrm{P}<0.01$; Figure $1 \mathrm{~B})$. In the formalin test, phase I $(0-5 \mathrm{~min})$ and phase II $(15-30 \mathrm{~min})$ corresponded to neurogenic and inflammatory pain, respectively. Tramadol, a well-known typical central antinociceptive medicine, strongly reduced pain scores in phase I $(\mathrm{P}<0.05$; Figure 1C) and showed slight abirritation in phase II.

PH significantly reduced acetic acid-induced writhing and stretching, and a nearly $41.8 \%$ reduction in writhing was observed at $1000 \mathrm{mg} / \mathrm{kg}(\mathrm{P}<0.01$; Figure $1 \mathrm{~A})$. In the hot-plate test, favorable activity against thermal stimulation was noted in PH-treated mice. Compared with the control group, $\mathrm{PH}(1000 \mathrm{mg} / \mathrm{kg})$ administration extended the latency period by nearly $40.2 \%(\mathrm{P}<0.01$; Figure 1B).

The antinociceptive effects of PH were further detected in phase I and phase II using the formalin test. PH $(1000 \mathrm{mg} / \mathrm{kg})$ displayed inhibitory effects on pain in both phases, with inhibition rates of $46.3 \%$ (phase I) and $57.0 \%$ (phase II) compared with the control group (P $<0.05$; Figure 1C). Different from $1000 \mathrm{mg} / \mathrm{kg}, \mathrm{PH}$ at a dose of $500 \mathrm{mg} / \mathrm{kg}$ only alleviated formalin-induced pain behavior in phase II $(\mathrm{P}<0.001$; Figure 1C) and had little effect in phase I.

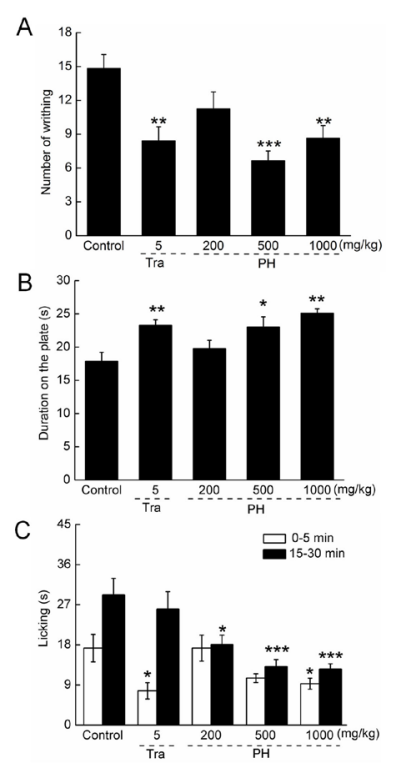

Figure 1. Effects of $\mathrm{PH}$ and tramadol based on the (A) acetic acid-induced writhing test, $(\mathbf{B})$ hot plate test, and $(\mathbf{C})$ formalin test in BALB/c mice. Mice were orally treated with D.D. water, tramadol (5 mg/kg), and PH (200 to $1000 \mathrm{mg} / \mathrm{kg}$ ) for 7 days. At $30 \mathrm{~min}$ after the last treatment, the number of body writhing events was calculated within $20 \mathrm{~min}$ in the acetic acidinduced writhing test (A). The pain threshold of each experimental mouse in a hot plate test was recorded (B). Nociceptive behaviors, including paw licking, were scored within $30 \mathrm{~min}$ in a formalin test $(\mathbf{C})$. Data are reported as means \pm SEM $(\mathrm{N}$ $=10) . * \mathrm{P}<0.05, * * \mathrm{P}<0.01$, and $* * * \mathrm{P}<0.001$ versus control group. ANOVA was followed by the Dunn test.

Genetics and Molecular Research 15 (3): gmr.15038996 


\section{Regulatory effects of PH on levels of nNOS in the hypothalamus}

nNOS is concentrated in the superficial dorsal horn of the spinal cord and the dorsal root ganglia, and it plays a key role in pain processing (Lu et al., 2014). Both tramadol and PH strongly suppressed nNOS levels after $30 \mathrm{~s}$ of thermal stimulation in mice $(\mathrm{P}<0.05$, Figure 2). $\mathrm{PH}$ administration at doses of $200 \mathrm{mg} / \mathrm{kg}$ and $1000 \mathrm{mg} / \mathrm{kg}$ resulted in 18.4 and $16.7 \%$ decreases in hypothalamus nNOS levels, respectively $(\mathrm{P}<0.05$, Figure 2$)$.

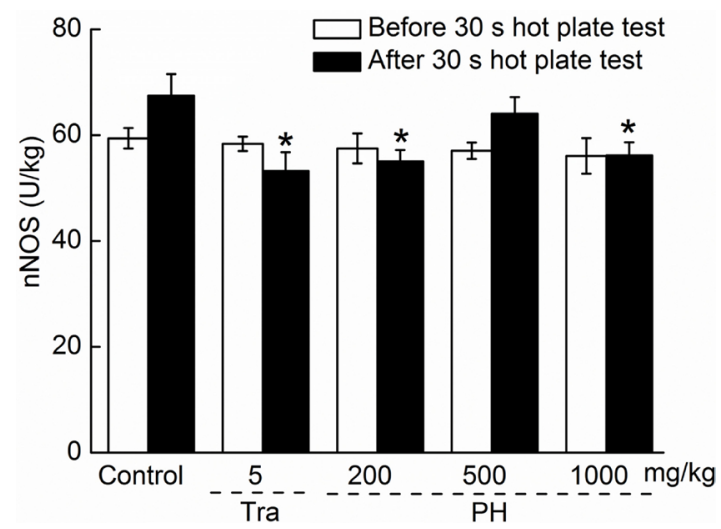

Figure 2. Mice were orally treated with D.D. water, tramadol $(5 \mathrm{mg} / \mathrm{kg})$, and PH (200 to $1000 \mathrm{mg} / \mathrm{kg}$ ) for 7 days and the hypothalamus was collected before and after the 30-s hot plate test. The levels of nNOS in the hypothalamus were analyzed by ELISA. Data are reported as means $\pm \mathrm{SEM}(\mathrm{N}=10) . * \mathrm{P}<0.05$ versus the control group. ANOVA was followed by the Dunn test.

\section{Regulatory effects of PH on monoamine neurotransmitters}

Compared with control and tramadol-treated mice, $\mathrm{PH}$ regulated the levels of 5-HT and DA in the serum and hypothalamus before 30 -s pain stimulation $(\mathrm{P}<0.05$, Figures 3,4$)$. After the hot plate test, a $66.8 \%$ enhancement in the 5 -HT serum concentration in tramadoltreated mice and a $113.9 \%$ increment in $\mathrm{PH}(1000 \mathrm{mg} / \mathrm{kg})$-treated mice were observed $(\mathrm{P}<$ 0.001 , Figure 3A) compared with the levels in control mice. The enhanced levels of 5-HT were still observed in the hypothalamus of tramadol- and PH-treated mice after 30-s thermal pain stimulation compared with the control mice $(\mathrm{P}<0.05$, Figure $3 \mathrm{~B})$.
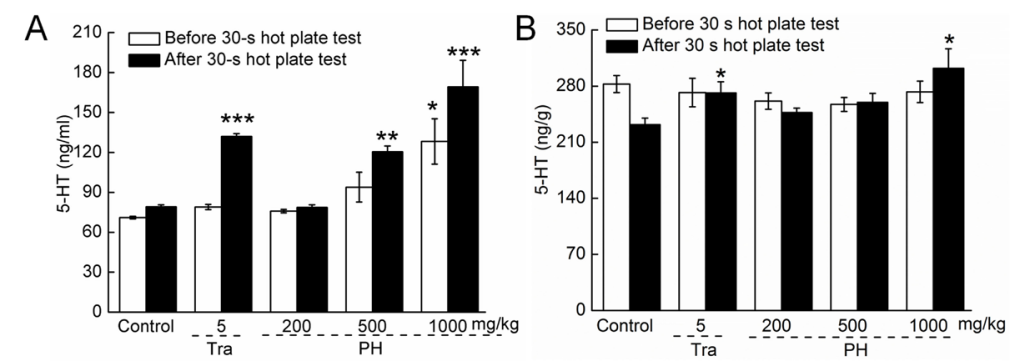

Figure 3. Before and after 30-s thermal stimulation, blood samples and hypothalamus tissues were collected, and the levels of 5-HT in the serum (A) and hypothalamus (B) were analyzed using ELISA. Data are reported as means \pm SEM $(\mathrm{N}=10) . * \mathrm{P}<0.05,{ }^{*} \mathrm{P}<0.01$, and ${ }^{* * *} \mathrm{P}<0.001$ versus the control group. ANOVA was followed by the Dunn test. 
Similar to tramadol, PH administration (from 200 to $1000 \mathrm{mg} / \mathrm{kg}$ ) decreased serum DA levels by 39.7 to $42.2 \%$ after $30 \mathrm{~s}$ of thermal stimulation compared with the control mice $(\mathrm{P}<$ 0.01 ; Figure $4 \mathrm{~A})$. In the hypothalamus, PH $(1000 \mathrm{mg} / \mathrm{kg})$ reduced DA levels by 14.3 and $27.6 \%$ before and after 30-s thermal pain stimulation compared with control group $(\mathrm{P}<0.01$; Figure 4B).
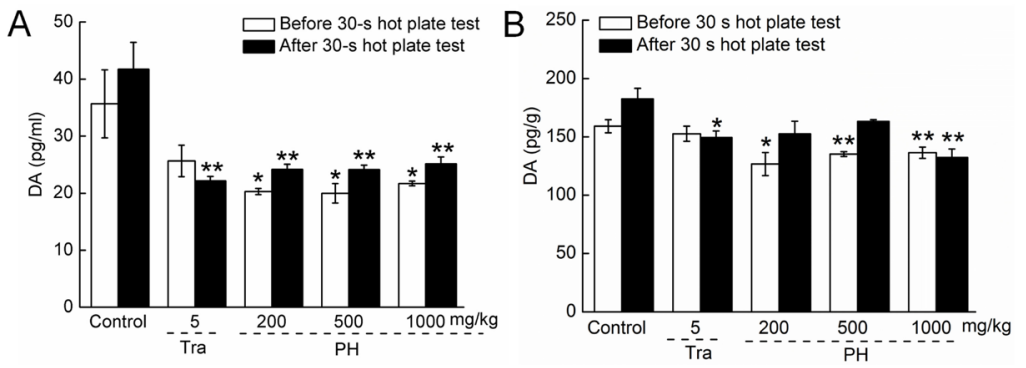

Figure 4. BALB/c mice were orally treated with D.D. water, tramadol (5 mg/kg), and PH (200 to $1000 \mathrm{mg} / \mathrm{kg})$ for seven days, and the levels of DA in the serum (A) and hypothalamus (B) were analyzed before and after the 30-s hot plate test using ELISA. Data are reported as means $\pm \mathrm{SEM}(\mathrm{N}=10) .{ }^{*} \mathrm{P}<0.05$ and ${ }^{* *} \mathrm{P}<0.01$ versus the control group. ANOVA was followed by the Dunn test.

\section{Mechanisms involved in PH-mediation}

Pre-treatment with atropine $(5 \mathrm{mg} / \mathrm{kg})$ and glibenclamide $(2 \mathrm{mg} / \mathrm{kg})$ significantly limited PH-mediated abirritation in the hot plated test, as evidenced by the reduced latency period of PHtreated mice $(\mathrm{P}<0.05$, Figure $5 \mathrm{D}$ and $\mathrm{E})$. No significant inhibitory effects on $\mathrm{PH}$-mediated abirritation were noted in mice pre-treated with naloxone $(1 \mathrm{mg} / \mathrm{kg})$, yohimbine $(2 \mathrm{mg} / \mathrm{kg})$, nimodipine $(10$ $\mathrm{mg} / \mathrm{kg}$ ), or methylene blue (10 mg/kg) (Figure 5A, B, C, and F). Treatment with methylene blue alone strongly extended the latency period of mice during the hot plate test $(\mathrm{P}<0.05$, Figure $5 \mathrm{C})$.

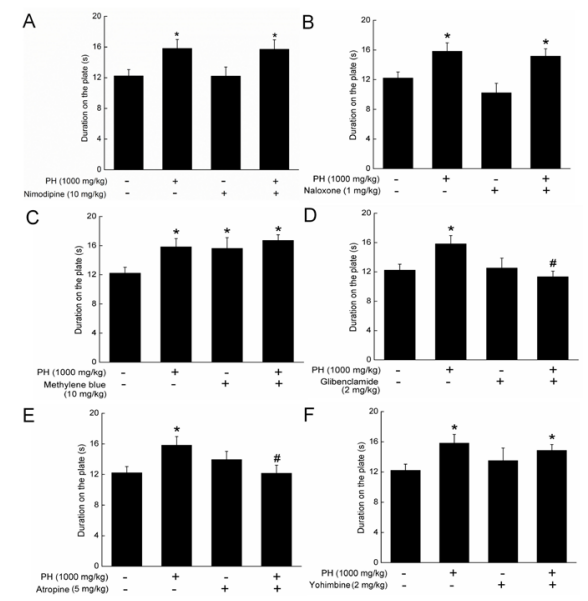

Figure 5. BALB/c mice were pre-treated with nimodipine $(10 \mathrm{mg} / \mathrm{kg})(\mathbf{A})$, naloxone $(1 \mathrm{mg} / \mathrm{kg})(\mathbf{B})$, methylene blue $(10 \mathrm{mg} / \mathrm{kg})(\mathbf{C})$, glibenclamide $(2 \mathrm{mg} / \mathrm{kg})(\mathbf{D})$, atropine $(5 \mathrm{mg} / \mathrm{kg})(\mathbf{E})$, and yohimbine $(2 \mathrm{mg} / \mathrm{kg})(\mathbf{F})$ via intraperitoneal injection, following by oral treatment with $\mathrm{PH}(1000 \mathrm{mg} / \mathrm{kg})$ or D.D. water. After $30 \mathrm{~min}$, a hot plate test was performed and the paw withdrawal latency for each mouse was recorded. Data are reported as means $\pm \mathrm{SEM}(\mathrm{N}=10) . * \mathrm{P}<0.05$ versus the control group; ${ }^{\#} \mathrm{P}<0.05$ versus mice treated with $\mathrm{PH}$ only. ANOVA was followed by the Dunn test. 


\section{DISCUSSION}

The present study provides the first experimental evidence that the PH mycelium has remarkable antinociceptive effects in various animal models. As a crude drug, multieffective components can be found in $\mathrm{PH}$. As reported previously, many natural products exhibit various pharmacological activities in a non-dose dependent manner (Ma et al., 2015). Similarly, our data were consistent with previous studies showing that PH has antinociceptive effects in a non-dose dependent manner. Acetic acid-induced writhing has been used as a screening tool to assess analgesic or anti-inflammatory agents (Pinheiro et al., 2010). The release of mediators involved in acetic acid stimulation, such as histamine, serotonin, and cytokines, helps to increase vascular permeability, reduce the threshold of nociception, and stimulate the nerve terminal of nociceptive fibers (da Silva Guerra et al., 2011). PH, which exhibited antinociceptive activity, not only inhibited acetic acid-induced writhing in mice, but also prolonged mouse reaction times in the hot plate test; it is related to the central nervous system (Srinivasan et al., 2003). In a formalin test, the initial acute phase (phase I, 0-5 min) corresponds to the neurogenic phase, in which paws are directly stimulated by the release of substance P. Following a relatively short quiescent period, the late phase (phase II, 15-30 min) refers to the inflammation pain response, which involves the release of histamine, serotonin, and prostaglandin (Devaraj et al., 2010). Tramadol, a typical central antinociceptive medicine, strongly reduces pain in phase I, while peripherally active drugs selectively inhibit phase II responses (Rauf et al., 2015). In our previous experiment, we verified that PH shows no effects on autonomic activity and prolongs the residence time in a Rota-rod test (Wang et al., 2015). Collectively, the antinociceptive effects of PH mainly occur via the central nervous system.

Among monoamine neurotransmitters, 5-HT shows essentially pro-nociceptive effects at the periphery and anti-nociceptive effects when it is injected directly at the spinal cord level (Viguier et al., 2013). 5-HT is widely accepted as a key neurotransmitter in the pathophysiology of migraines, and low levels of 5-HT are found in patients who suffer from chronic daily headaches (le Grand et al., 2011). System administration with the serotonin precursor 5-hydroxytryptophan significantly increases serotonin and provides somatic analgesia (Hall et al., 2015). Moreover, the non-selective serotonin antagonist metergoline antagonizes mirtazapine-induced antinociceptive effects (Schreiber et al., 2002). Another monoamine neurotransmitter, DA, is involved in the processing of somatosensory information, including pain (Ogata et al., 2015). Dopaminergic transmission in the periaqueductal grey and thalamus is associated with fear-conditioned analgesia (Finn et al., 2006). Agents that enhance the reactivity of animals to nociceptive stimuli show direct or indirect effects on dopaminergic receptors (Tulunay et al., 1975). Interestingly, the serotonergic system controls the activity of DA neurons in the ventral tegmental area via 5-HT2C receptors (Di Giovanni et al., 2001). $p$-Chloroamphetamine, a 5-hydroxytryptamine-releasing drug, induces hyperthermia in mice, and this effect is mediated by the dopaminergic system, including dopamine release and dopamine $\mathrm{D}_{1}$ receptor activation (Sugimoto et al., 2001). Our results revealed that $\mathrm{PH}$ enhances 5-HT levels and reduces the DA concentration after $30 \mathrm{~s}$ of thermal pain stimulation. In general, the regulatory role of PH on monoamine neurotransmitters (5-HT and DA) contributes to the antinociceptive activity. In our ongoing experiments, we are applying 5-HT antagonists to confirm the role of 5-HT and the relationship between DA and 5-HT.

In an antagonist-combined hot plate test, naloxone, methylene blue, nimodipine, and

Genetics and Molecular Research 15 (3): gmr.15038996 
yohimbine failed to inhibit the PH-enhanced thermotolerance of mice, which suggests that opioid receptors, guanylyl cyclase, $\mathrm{Ca}^{2+}$ channels, and a2-adrenoceptor do not contribute to the antinociception of PH (Shi et al., 2011). Even though opioids act rapidly and have a therapeutic effect on pain, chronic administration leads to analgesic tolerance and physical dependence. Based on the safety evaluation in our preliminary experiment, $\mathrm{PH}$ may be an ideal anti-nociceptive drug without hazardous side effects. Future studies will examine its addictive properties. Glibenclamide and atropine strongly suppressed PH-mediated antinociceptive activity in the hot plate test, indicating that $\mathrm{K}_{\text {ATP }}$ channels and $\mathrm{mAChR}$ are involved. Glibenclamide is commonly used to identify the roles of $\mathrm{K}_{\text {ATP }}$ channels during antinociception (Rodrigues and Duarte, 2000). Sodium nitroprusside, a NO donor, exerts peripheral antinociceptive action via $\mathrm{K}_{\text {ATP }}$ channels (Soares et al., 2000). Morphine acts on primary nociceptive neurons to activate PI $3 \mathrm{~K} \gamma / \mathrm{AKT}$ signaling, consequently stimulating the $\mathrm{nNOS} / \mathrm{NO} / \mathrm{K}_{\mathrm{ATP}}$ channel to directly block inflammatory hypernociception (Cunha et al., 2010). Upregulated nNOS expression in dorsal root ganglia neurons during nerve injury promotes NO synthesis, and further leads to neuronal excitability, which enhances pain hypersensitivity (Masliukov et al., 2015). The $N$-methyl-D-aspartate (NMDA) receptor contributes to central nervous system sensitization and chronic pain by activating nNOS (Lee et al., 2015). Reduced nNOS levels in PH-treated mice were observed. The important role of $n N O S / K_{\text {ATP }}$ channel in the antinociceptive activity of $\mathrm{PH}$ was confirmed in our preliminary research; however, additional experiments focusing on the detailed mechanisms will be performed.

$\mathrm{mAChR}$ is important for the regulation of physiological functions, including nociception. In $\mathrm{mAChR}$ knockout mice, it has been unequivocally demonstrated that $\mathrm{mAChR}$ participates in muscarinic agonist-mediated analgesia (Chen et al., 2005). Cobrotoxin inhibits T-type $\mathrm{Ca}^{2+}$ channel currents via $\mathrm{M} 3 \mathrm{mAChR}$, which contributes to its antinociceptive effects in mice (Zhang et al., 2011). Muscarinic analgesia is exclusively mediated by a combination of M-2 and M-4 $\mathrm{mAChR}$ at spinal and supraspinal sites. Galantamine, a weak acetylcholine esterase (AChE) inhibitor, improves apomorphine-induced prepulse inhibition deficits by stimulating mAChR, which facilitates ACh release in the prefrontal cortex and hippocampus of mice (Yano et al., 2009). ACh is excitatory with respect to the hypothalamic-pituitary-adrenal (HPA) axis. The activation of the HPA axis plays the central role in formalin-induced persistent pain (Finn et al., 2004). Interestingly, during stress, excessive HPA activation can be prevented by the release of mesocortical DA (Sullivan and Dufresne, 2006). According to our data, PH-mediated antinociceptive activities are associated with $\mathrm{mAChR}$, which may show crosstalk in DA.

In conclusion, the $\mathrm{PH}$ mycelium exerts significant antinociception effects on mouse models via multiple pathways, including monoamines, $\mathrm{nNOS} / \mathrm{K}_{\mathrm{ATP}}$ channel, and $\mathrm{mAChR}$. Studies of the precise underlying mechanisms and the relationships among pathways are ongoing in our group. The present results provide the first experimental evidence that $\mathrm{PH}$ is an effective agent for pain therapy.

\section{Conflicts of interest}

The authors declare no conflict of interest.

\section{ACKNOWLEDGMENTS}

Research supported by the Science and Technology Development Program of Jilin

Genetics and Molecular Research 15 (3): gmr.15038996 
Province in China (Grant \#20160520036JH), the Postdoctoral Science Foundation of China (Grant \#2016M591495), and the Postdoctoral Scientific Research Project of Jilin Province in China.

\section{REFERENCES}

Bonkanka CX, Sánchez-Mateo CdelC and Rabanal RM (2011). Antinociceptive activity of Hypericum grandifolium Choisy in mice. J. Nat. Med. 65: 122-128. http://dx.doi.org/10.1007/s11418-010-0473-y

Chen SR, Wess J and Pan HL (2005). Functional activity of the M2 and M4 receptor subtypes in the spinal cord studied with muscarinic acetylcholine receptor knockout mice. J. Pharmacol. Exp. Ther. 313: 765-770. http://dx.doi. org/10.1124/jpet.104.082537

Cui XJ, Sun YL, You SF, Mo W, et al. (2013). Effects of Qishe Pill, a compound traditional Chinese herbal medicine, on cervical radiculopathy: study protocol for a randomized controlled trial. Trials 14: 322. http://dx.doi. org/10.1186/1745-6215-14-322

Cunha TM, Roman-Campos D, Lotufo CM, Duarte HL, et al. (2010). Morphine peripheral analgesia depends on activation of the PI3Kgamma/AKT/nNOS/NO/KATP signaling pathway. Proc. Natl. Acad. Sci. USA 107: 4442-4447. http:// dx.doi.org/10.1073/pnas.0914733107

Devaraj S, Esfahani AS, Ismail S, Ramanathan S, et al. (2010). Evaluation of the antinociceptive activity and acute oral toxicity of standardized ethanolic extract of the rhizome of Curcuma xanthorrhiza Roxb. Molecules 15: 2925-2934. http://dx.doi.org/10.3390/molecules 15042925

Di Giovanni G, Di Matteo V, La Grutta V and Esposito E (2001). m-Chlorophenylpiperazine excites non-dopaminergic neurons in the rat substantia nigra and ventral tegmental area by activating serotonin-2C receptors. Neuroscience 103: 111-116. http://dx.doi.org/10.1016/S0306-4522(00)00561-3

Finn DP, Beckett SR, Roe CH, Madjd A, et al. (2004). Effects of coadministration of cannabinoids and morphine on nociceptive behaviour, brain monoamines and HPA axis activity in a rat model of persistent pain. Eur. J. Neurosci. 19: 678-686. http://dx.doi.org/10.1111/j.0953-816X.2004.03177.x

Finn DP, Jhaveri MD, Beckett SR, Madjd A, et al. (2006). Behavioral, central monoaminergic and hypothalamopituitary-adrenal axis correlates of fear-conditioned analgesia in rats. Neuroscience 138: 1309-1317. http://dx.doi. org/10.1016/j.neuroscience.2005.11.063

da Silva Guerra AS, Malta DJ, Laranjeira LP, Maia MB, et al. (2011). Anti-inflammatory and antinociceptive activities of indole-imidazolidine derivatives. Int. Immunopharmacol. 11: 1816-1822. http://dx.doi.org/10.1016/j. intimp.2011.07.010

Hall JD, DeWitte C, Ness TJ and Robbins MT (2015). Serotonin enhances urinary bladder nociceptive processing via a 5-HT3 receptor mechanism. Neurosci. Lett. 604: 97-102. http://dx.doi.org/10.1016/j.neulet.2015.07.048

le Grand SM, Supornsilpchai W, Saengjaroentham C and Srikiatkhachorn A (2011). Serotonin depletion leads to cortical hyperexcitability and trigeminal nociceptive facilitation via the nitric oxide pathway. Headache 51: 1152-1160. http://dx.doi.org/10.1111/j.1526-4610.2011.01931.x

Lee WH, XuZ, Ashpole NM, Hudmon A, etal.(2015). Small molecule inhibitors of PSD95-nNOS protein-protein interactions as novel analgesics. Neuropharmacology 97: 464-475. http://dx.doi.org/10.1016/j.neuropharm.2015.05.038

Li JC, Shen XF, Meng XL, Zhang Y, et al. (2011). Analgesic effect and mechanism of the three TCM-herbal drugcombination Tou Feng Yu pill on treatment of migraine. Phytomedicine 18: 788-794. http://dx.doi.org/10.1016/j. phymed.2011.01.008

Lu Y, Hu J, Zhang Y and Dong C (2014). Spinal neuronal NOS activation mediates intrathecal fentanyl preconditioning induced remote cardioprotection in rats. Int. Immunopharmacol. 19: 127-131. http://dx.doi.org/10.1016/j. intimp.2014.01.013

Ma L, Zhang S and Du M (2015). Cordycepin from Cordyceps militaris prevents hyperglycemia in alloxan-induced diabetic mice. Nutr. Res. 35: 431-439. http://dx.doi.org/10.1016/j.nutres.2015.04.011

Magiera S, Gülmez Ş, Michalik A and Baranowska I (2013). Application of statistical experimental design to the optimisation of microextraction by packed sorbent for the analysis of nonsteroidal anti-inflammatory drugs in human urine by ultra-high pressure liquid chromatography. J. Chromatogr. A 1304: 1-9. http://dx.doi.org/10.1016/j. chroma.2013.06.047

Masliukov PM, Moiseev KY, Korzina MB and Porseva VV (2015). Development of nNOS-positive neurons in the rat sensory ganglia after capsaicin treatment. Brain Res. 1618: 212-221. http://dx.doi.org/10.1016/j.brainres.2015.05.040

McCarberg BH (2011). Pain management in primary care: strategies to mitigate opioid misuse, abuse, and diversion.

Genetics and Molecular Research 15 (3): gmr.15038996 
Postgrad. Med. 123: 119-130. http://dx.doi.org/10.3810/pgm.2011.03.2270

Nishizawa K, Torii K, Kawasaki A, Katada M, et al. (2007). Antidepressant-like effect of Cordyceps sinensis in the mouse tail suspension test. Biol. Pharm. Bull. 30: 1758-1762. http://dx.doi.org/10.1248/bpb.30.1758

Ogata M, Noda K, Akita H and Ishibashi H (2015). Characterization of nociceptive response to chemical, mechanical, and thermal stimuli in adolescent rats with neonatal dopamine depletion. Neuroscience 289: 43-55. http://dx.doi. org/10.1016/j.neuroscience.2015.01.002

Pinheiro MM, Bessa SO, Fingolo CE, Kuster RM, et al. (2010). Antinociceptive activity of fractions from Couroupita guianensis Aubl. leaves. J. Ethnopharmacol. 127: 407-413. http://dx.doi.org/10.1016/j.jep.2009.10.025

Rauf A, Khan R, Raza M, Khan H, et al. (2015). Suppression of inflammatory response by chrysin, a flavone isolated from Potentilla evestita Th. Wolf. In silico predictive study on its mechanistic effect. Fitoterapia 103: 129-135. http:// dx.doi.org/10.1016/j.fitote.2015.03.019

Rodrigues AR and Duarte ID (2000). The peripheral antinociceptive effect induced by morphine is associated with ATPsensitive K(+) channels. Br. J. Pharmacol. 129: 110-114. http://dx.doi.org/10.1038/sj.bjp.0703038

Rossato MF, Oliveira SM, Trevisan G, Rotta M, et al. (2015). Structural improvement of compounds with analgesic activity: AC-MPF4, a compound with mixed anti-inflammatory and antinociceptive activity via opioid receptor. Pharmacol. Biochem. Behav. 129: 72-78. http://dx.doi.org/10.1016/j.pbb.2014.12.001

Schreiber S, Rigai T, Katz Y and Pick CG (2002). The antinociceptive effect of mirtazapine in mice is mediated through serotonergic, noradrenergic and opioid mechanisms. Brain Res. Bull. 58: 601-605. http://dx.doi.org/10.1016/S0361$\underline{9230(02) 00825-0}$

Shi GB, Zhao MH, Zhao QC, Huang Y, et al. (2011). Mechanisms involved in the antinociception of petroleum ether fraction from the EtOH extract of Chrysanthemum indicum in mice. Phytomedicine 18: 609-616. http://dx.doi. org/10.1016/j.phymed.2010.10.014

Soares AC, Leite R, Tatsuo MA and Duarte ID (2000). Activation of ATP-sensitive K(+) channels: mechanism of peripheral antinociceptive action of the nitric oxide donor, sodium nitroprusside. Eur. J. Pharmacol. 400: 67-71. http://dx.doi.org/10.1016/S0014-2999(00)00355-1

Srinivasan K, Muruganandan S, Lal J, Chandra S, et al. (2003). Antinociceptive and antipyretic activities of Pongamia pinnata leaves. Phytother. Res. 17: 259-264. http://dx.doi.org/10.1002/ptr.1126

Sudo RT, Neto ML, Monteiro CE, Amaral RV, et al. (2015). Antinociceptive effects of hydroalcoholic extract from Euterpe oleracea Mart. (Açaí) in a rodent model of acute and neuropathic pain. BMC Complement. Altern. Med. 15: 208. http://dx.doi.org/10.1186/s12906-015-0724-2

Sugimoto Y, Ohkura M, Inoue K and Yamada J (2001). Involvement of serotonergic and dopaminergic mechanisms in hyperthermia induced by a serotonin-releasing drug, p-chloroamphetamine in mice. Eur. J. Pharmacol. 430: 265268. http://dx.doi.org/10.1016/S0014-2999(01)01386-3

Sullivan RM and Dufresne MM (2006). Mesocortical dopamine and HPA axis regulation: role of laterality and early environment. Brain Res. 1076: 49-59. http://dx.doi.org/10.1016/j.brainres.2005.12.100

Tian Y, Teng LR, Song JJ, Meng QF, et al. (2014). Studies on the analgesic activities of Jia-Yuan-Qing pill and its safety evaluation in mice. Protoplasma 251: 1245-1253. http://dx.doi.org/10.1007/s00709-014-0637-9

Trang T, Al-Hasani R, Salvemini D, Salter MW, et al. (2015). Pain and Poppies: The Good, the Bad, and the Ugly of Opioid Analgesics. J. Neurosci. 35: 13879-13888. http://dx.doi.org/10.1523/JNEUROSCI.2711-15.2015

Tulunay FC, Sparber SB and Takemori AE (1975). The effect of dopaminergic stimulation and blockade on the nociceptive and antinociceptive responses of mice. Eur. J. Pharmacol. 33: 65-70. http://dx.doi.org/10.1016/0014$\underline{2999(75) 90139-9}$

Viguier F, Michot B, Hamon M and Bourgoin S (2013). Multiple roles of serotonin in pain control mechanisms-implications of 5-HT and other 5-HT receptor types. Eur. J. Pharmacol. 716: 8-16. http://dx.doi.org/10.1016/j. ejphar.2013.01.074

Wang J, Li LZ, Liu YG, Teng LR, et al. (2015). Investigations on the antifatigue and antihypoxic effects of Paecilomyces hepiali extract. Mol. Med. Rep. 13: 1861-1868. http://dx.doi.org/10.2119/molmed.2014.00240

Wu Z, Zhang M, Xie M, Dai Z, et al. (2016). Extraction, characterization and antioxidant activity of mycelial polysaccharides from Paecilomyces hepiali HN1. Carbohydr. Polym. 137: 541-548. http://dx.doi.org/10.1016/j.carbpol.2015.11.010

Yano K, Koda K, Ago Y, Kobayashi H, et al. (2009). Galantamine improves apomorphine-induced deficits in prepulse inhibition via muscarinic ACh receptors in mice. Br. J. Pharmacol. 156: 173-180. http://dx.doi.org/10.1111/j.14765381.2008.00037.x

Zhang Y, Zhang L, Wang F, Zhang Y, et al. (2011). Activation of M3 muscarinic receptors inhibits T-type Ca(2+) channel currents via pertussis toxin-sensitive novel protein kinase $\mathrm{C}$ pathway in small dorsal root ganglion neurons. Cell. Signal. 23: 1057-1067. http://dx.doi.org/10.1016/j.cellsig.2011.02.001

Genetics and Molecular Research 15 (3): gmr.15038996 